\title{
Historical assessment
}

\author{
Sarah E. Gergel ${ }^{1}$ and Ruth H. Thurstan ${ }^{2}$
}

1'DEPARTMENT OF FOREST AND CONSERVATION SCIENCES, UNIVERSITY OF BRITISH COLUMBIA, VANCOUVER, CANADA

${ }^{2}$ CENTRE FOR ECOLOGY AND CONSERVATION, COLLEGE OF LIFE AND ENVIRONMENTAL SCIENCES, UNIVERSITY OF EXETER, PENRYN, UK

\section{Key methods discussed in this chapter}

Methods related to data obtained from sediment cores, archaeological/zooarchaeological materials, dendrochronology/sclerochronology, land surveys, historical aerial photography, satellite remote sensing, documentary sources, governmental data, interviews and oral histories

\section{Connections to other chapters}

Historical assessment methods may include participatory techniques (i.e. interviews and participatory mapping, see Chapters 7 and 8) or use biophysical information obtained from historical maps, satellite imagery (Chapter 24), sediment cores, tree rings and ancient artefacts. Historical analysis may involve discerning the content and key themes found in old documents and news sources, spatial mapping and analysis (Chapter 24), as well as quantitative statistical analysis of a government census or survey (Chapters 18 and 19).

\section{Introduction}

Historical assessment is the task of reconstructing the long-term dynamics of a social-ecological systems (SES) over time and may span years, centuries or millennia (Tomscha et al. 2016). Approaches can be qualitative or quantitative. While historical reconstruction may incorporate very direct measurements of phenomena, often more indirect indicators and proxies of a system must be used instead. The general goal of historical assessment is to determine if and how an SES has changed over time. Historical assessment can help us to understand baselines (e.g. initial starting conditions) (Morgan, Gergel, and Coops 2010) and provide context for recent changes (e.g. are recent changes large or small compared to historical changes?) (Rosenberg et al. 2005).

Historical assessment enjoys the benefits - as well as the challenges - of contributions from a variety of disciplines, a plurality of data sources and a diverse array of methodological approaches. Although historical assessment draws on many disciplines, historical ecology 


\section{SUMMARY TABLE: HISTORICAL ASSESSMENT}

\begin{tabular}{|c|c|}
\hline DISCIPLINARY BACKGROUND & KNOWLEDGE TYPE \\
\hline $\begin{array}{l}\text { The methods in this chapter are derived } \\
\text { from or have most commonly been used in: } \\
\text { Historical Ecology, Environmental } \\
\text { History, Palaeoecology, Climatology, } \\
\text { Archaeology, Ethnography, Landscape } \\
\text { Ecology, Anthropology, Environmental } \\
\text { Social Sciences, Human Geography, } \\
\text { Maritime History, Social History }\end{array}$ & $\begin{array}{l}\text { The methods in this chapter are primarily } \\
\text { used to generate the following types of } \\
\text { knowledge: } \\
\text { - Descriptive } \\
\text { - Exploratory } \\
\text { - Explanatory }\end{array}$ \\
\hline RESEARCH APPROACH & PURPOSE OF METHOD \\
\hline $\begin{array}{l}\text { The methods in this chapter originate } \\
\text { from or most commonly adopt the } \\
\text { following research approaches: } \\
\text { - Analytical/objective } \\
\text { - Interpretive/subjective }\end{array}$ & $\begin{array}{l}\text { The most common purposes of using the } \\
\text { methods in this chapter are: } \\
\text { - Data collection/generation } \\
\text { - System understanding }\end{array}$ \\
\hline TEMPORAL DIMENSION & SYSTEMIC FEATURES AND PROCESSES \\
\hline $\begin{array}{l}\text { The methods in this chapter are most } \\
\text { commonly applied to the following } \\
\text { temporal dimensions: } \\
\text { - Recent past (post-1700s) } \\
\text { - Pre-industrial revolution (pre-1700s) }\end{array}$ & \multirow[t]{2}{*}{$\begin{array}{l}\text { While most methods can do many } \\
\text { things, the methods in this chapter are } \\
\text { particularly good (i.e. go-to methods) for } \\
\text { addressing the following: } \\
\text { - Social-ecological interactions } \\
\text { over time } \\
\text { - Adaptation and self-organisation } \\
\text { - Regime shifts }\end{array}$} \\
\hline $\begin{array}{l}\text { The methods in this chapter are primarily } \\
\text { either or both: } \\
\text { - Non-spatial } \\
\text { - Explicitly spatial } \\
\text { The methods in this chapter are most } \\
\text { commonly applied at the following } \\
\text { spatial scales: } \\
\text { - Local } \\
\text { - Regional (provincial/state } \\
\text { to continental) } \\
\text { - Global } \\
\text { - Multiple places/sites around the world }\end{array}$ & \\
\hline
\end{tabular}


Table 25.1 Summary of key data sources or types used in historical assessment

\begin{tabular}{|c|c|c|}
\hline Data source or type & Description & References \\
\hline Sediment cores & $\begin{array}{l}\text { Sediment cores often contain floral and faunal } \\
\text { remains, which, alongside dating and isotopic } \\
\text { techniques, enable inferences about the ecological } \\
\text { communities that existed in the past, changes } \\
\text { that occurred and the potential drivers of change. } \\
\text { Depending on the environment being sampled, } \\
\text { the length and depth of the sediment core and } \\
\text { the rate of sedimentation/erosion, sediment } \\
\text { cores may be used to infer changes spanning } \\
\text { decades to millions of years into the past. } \\
\text { Methods include stable isotope analysis and core } \\
\text { sediment composition or heavy-metal analysis } \\
\text { to demonstrate the scale, direction and drivers } \\
\text { of environmental change (see also Chapter } 6 \text { : } \\
\text { Ecological field data collection). }\end{array}$ & $\begin{array}{l}\text { Key introductory text } \\
\text { Last and Smol } 2001 \\
\text { Applications to SES } \\
\text { Jeffers, Nogué, and } \\
\text { Willis } 2015\end{array}$ \\
\hline $\begin{array}{l}\text { Archaeological } \\
\text { materials }\end{array}$ & $\begin{array}{l}\text { Archaeological materials consist of artefacts, } \\
\text { architectural remains and cultural landscapes, } \\
\text { among many others. Archaeologists use both } \\
\text { quantitative and semi-quantitative measures to } \\
\text { compare changes in remains left behind. When } \\
\text { combined with dating techniques and other } \\
\text { sources, these approaches can be used to infer } \\
\text { the timing and drivers of change for hundreds } \\
\text { to tens of thousands of years in the past. Field } \\
\text { methods include surveys (remote or in-person) } \\
\text { and the excavation of sites. Post-excavation } \\
\text { analysis typically includes dating, classifying } \\
\text { or compositional analysis of artefacts and } \\
\text { archaeological features. }\end{array}$ & $\begin{array}{l}\text { Key introductory text } \\
\text { Gebhard } 2003 \\
\text { Applications to SES } \\
\text { Crumley } 2017\end{array}$ \\
\hline $\begin{array}{l}\text { Zooarchaeological } \\
\text { materials }\end{array}$ & $\begin{array}{l}\text { Animal remains excavated from archaeological } \\
\text { sites can be used to track changes in the presence, } \\
\text { abundance and/or size of the species. These data } \\
\text { can be used to infer social and ecological changes } \\
\text { through time as far back as hundreds to tens } \\
\text { of thousands of years ago. Analytical methods } \\
\text { are diverse and include determining the age at } \\
\text { death and biometry of animal remains, e.g. to } \\
\text { identify the timing of commencement of animal } \\
\text { domestication. }\end{array}$ & $\begin{array}{l}\text { Key introductory text } \\
\text { Gifford-Gonzalez } 2018 \\
\text { Applications to SES } \\
\text { Harland et al. 2016; } \\
\text { Wallman } 2018\end{array}$ \\
\hline $\begin{array}{l}\text { Dendrochronology } \\
\text { and } \\
\text { sclerochronology }\end{array}$ & $\begin{array}{l}\text { Both dendrochronology and sclerochronology } \\
\text { reconstruct past environmental changes in climate } \\
\text { and ecosystem productivity, which may reflect } \\
\text { natural and anthropogenic causes. }\end{array}$ & $\begin{array}{l}\text { Key introductory texts } \\
\text { Butler and Schöne 2017; } \\
\text { UWICER } 2017\end{array}$ \\
\hline
\end{tabular}


Dendrochronology examines tree rings over time spans of decades to centuries. These growth patterns reflect particular increments of time (i.e. seasonal, annual growth). Tree rings and scars can thus provide information on past climate and drought, cultural uses of trees (such as bark stripping), and traditional burning practices and fire suppression.

Sclerochronology studies the bands of new growth laid down in invertebrate shell and coral remains. Similar to tree rings, the study and dating of these growth patterns can be used to reconstruct information on environmental and climatic changes over periods of decades to centuries. Methods include dating of samples to determine their age or date of death, followed by growth trend estimation and statistical reconstruction of spatial and temporal variations in, for example, climate anomalies, using rate of growth as a proxy.

Land surveys

Historical maps, originally for surveying purposes, can be adapted for SES purposes ranging from mapping early transportation networks and vegetation change to carbon storage. In North America, General Land Office Notes and Land Surveys exist for the USA and Canada. In European countries these resources are even older, more extensive and phenomenally detailed. In some cases created by royal decree, these maps can be a source of information regarding cultural and economic priorities.

Cartography is the study and practice of making maps. Georeferencing of chart features to geographic coordinates enables the comparison of charts and their features through time and space (the same principles apply for historical aerial photography).

Historical aerial photography
Historical photography can be used to map long-term patterns of landscape change from anthropogenic and/or biophysical causes. Historical photos can divulge 'baseline' or reference conditions preceding industrial expansion in some regions.

Oblique imagery (captured perpendicular to the earth's surface) is routinely available for many parts of the world, beginning in the 1950s and occasionally in the 1930s. New sources of declassified 'cold war era' imagery are also emerging. For some nation states, the archival resources of a former colonial power or occupying country must be consulted in order to find historical imagery. Turn-of-the-century ground-based images are available in rare cases, which can represent historical vistas and viewsheds.
Applications to SES

Smith, Mackie, and Sumpter 2005;

Stahle and Dean 2010

Key introductory text Fuchs et al. 2015

Applications to SES

Rhemtulla, Mladenoff, and Clayton 2009

Key introductory text Morgan, Gergel, and Coops 2010

Applications to SES Coomes, Takasaki, and Rhemtulla 2011 
Table 25.1 (Continued)

\begin{tabular}{|c|c|c|}
\hline Data source or type & Description & References \\
\hline $\begin{array}{l}\text { Satellite remote } \\
\text { sensing }\end{array}$ & $\begin{array}{l}\text { Satellite imagery can be used to track long-term } \\
\text { dynamics of agriculture, forests, rivers, glacial } \\
\text { retreat, sea-level rise and urbanisation, to name a } \\
\text { few. The primary workhorse is the Landsat series } \\
\text { of satellites that have been providing repeat, } \\
\text { continuous, freely available imagery at } 30 \text { m spatial } \\
\text { resolution since the 1980s for many locations } \\
\text { globally. Another primary source of information } \\
\text { comes from a satellite sensor called Moderate } \\
\text { Resolution Imaging Spectroradiometer (MODIS), } \\
\text { which images the earth every one to two days. } \\
\text { Although at coarser spatial resolution, the temporal } \\
\text { frequency of MODIS makes it useful for climate } \\
\text { change and phenological applications, such as } \\
\text { tracking the timing of seasonal 'green-up' of } \\
\text { vegetation and degradation of vegetation (see also } \\
\text { Chapter 24: Spatial mapping and analysis). }\end{array}$ & $\begin{array}{l}\text { Key introductory text } \\
\text { Cohen and Goward } 2004 \\
\text { Applications to SES } \\
\text { Barbosa, Atkinson, and } \\
\text { Dearing 2015; } \\
\text { Eddy et al. } 2017\end{array}$ \\
\hline $\begin{array}{l}\text { Documentary } \\
\text { sources }\end{array}$ & $\begin{array}{l}\text { Documentary sources include government and } \\
\text { non-government publications such as Commissions } \\
\text { of Evidence, newspaper articles, popular media, } \\
\text { and art and travel publications, among many other } \\
\text { sources. Both quantitative and qualitative data may } \\
\text { be of interest. An analysis may combine data from } \\
\text { multiple sources, or multiple years from the same } \\
\text { source. Particular care must be taken in interpretation } \\
\text { to ensure that the context in which the data were } \\
\text { originally created or presented is well understood } \\
\text { and accounted for. Typical methods include source } \\
\text { criticism, which evaluates the reliability, context and } \\
\text { integrity of a source, and triangulation, which cross- } \\
\text { references different sources or approaches to validate } \\
\text { a finding. }\end{array}$ & $\begin{array}{l}\text { Key introductory texts } \\
\text { Hsieh and Shannon 2005; } \\
\text { Braun and Clarke } 2006 \\
\text { Applications to SES } \\
\text { Thurstan, Buckley, and } \\
\text { Pandolfi 2018; } \\
\text { Thurstan et al. } 2018\end{array}$ \\
\hline $\begin{array}{l}\text { Governmental/ } \\
\text { population census } \\
\text { statistics/ } \\
\text { health data }\end{array}$ & $\begin{array}{l}\text { Governmental census and survey data can } \\
\text { encompass a wide range of topics and may be } \\
\text { collected for distinct foci such as population, health } \\
\text { and sector-specific statistics. This information may } \\
\text { be collected quarterly, annually or every } 10 \text { years, } \\
\text { and at local, regional or national levels. Statistics } \\
\text { may include social and ecological factors, e.g. } \\
\text { landings of fish or numbers of fishers working from } \\
\text { a specific port. By design, these datasets primarily } \\
\text { emphasise quantitative information. These data } \\
\text { are often accompanied by important textual } \\
\text { explanations which not only provide important } \\
\text { context but can even be further analysed directly. } \\
\text { The methods of analysis can vary widely and will } \\
\text { depend on the question being asked, the granularity } \\
\text { of the data and the number of repeated data points. }\end{array}$ & $\begin{array}{l}\text { Key introductory text } \\
\text { Newsom, Jones, and } \\
\text { Hofer } 2012 \\
\text { Applications to SES } \\
\text { Renard, Rhemtulla, and } \\
\text { Bennett } 2015\end{array}$ \\
\hline
\end{tabular}


Data source or type Description

Structured and unstructured interviews and oral histories

\begin{abstract}
Retrospective analyses can be incorporated into interview methods by asking participants about their past observations, experiences and behaviours. These methods can also be combined with participatory mapping approaches to collect long-term spatial information. However, retrospective work should be undertaken with an appreciation of issues associated with recall bias and the shifting baselines syndrome, along with other potential issues associated with perception and memory recall. Methods such as timeline mapping and triangulation using other data sources can help to acknowledge and minimise biases of this nature (see Chapter 7 for a more detailed discussion of different interview methodologies and data types related to interviews).
\end{abstract}

\section{References}

Key introductory text

Zusman 2010

Applications to SES

Buckley et al. 2017;

Selgrath, Gergel, and

Vincent 2017

and environmental history play particularly important roles (McClenachan et al. 2015; see Table 25.1). As a result, the conceptual background, assumptions and level of quantitative and qualitative approaches behind any historical assessment can vary widely depending upon the researchers' disciplinary background, the sources available to them and the specific research question being examined. Interview techniques, for example, can provide rich detail on how people have used and influenced land- and seascapes (Selgrath, Gergel, and Vincent 2017). Archaeological and palaeo-ecological evidence can provide information on historical activities of humans along with the constraints under which they lived. New historical sources of geospatial information are becoming available as formerly classified mapping information becomes unclassified. Given their strengths, weakness and differences in spatio-temporal resolution, historical assessments are strongest when several methods are used in combination to build a more complete picture of long-term SES dynamics. To assess a recreational fishery, for example, Thurstan et al. (2018) used sources ranging from popular media articles, government statistical reports and early research surveys from the 19th century along with semi-structured interviews with current and retired fishers (in Thurstan et al. 2018, Table 2).

\section{SES problems and questions}

Historical assessment methods are routinely used to understand interactions between human and ecological communities and the outcomes of these interactions (Kittinger et al. 2015). Historical ecology is often used to study ecosystem change and to understand human use of resources through time. Historical ecology may also track the subsequent adaptation of human communities to environmental changes. Tackling these types of issues often includes the reconstruction of baseline ecosystem conditions and the characterisation of variation in periods with and without significant human impacts.

Some current topical challenges in historical social-ecological fields include the evaluation of shifting baselines (inter-generational differences in the perceptions of ecosystem baseline conditions), trade-offs among ecosystem services (the benefits that humans gain from nature and how these interact; Bennett, Peterson, and Gordon 2009) and shifts in the cultural importance of ecosystem services over time (Daniel et al. 2012). Trade-offs among 
ecosystem services have increasingly been evaluated over longer time frames (Renard, Rhemtulla, and Bennett 2015; Tomscha et al. 2016). Trade-offs resulting from historical agricultural expansion for food production, for example, may result in long-term problems for downstream water quality (Bennett, Peterson, and Gordon 2009).

Historical assessment methods must routinely assess similarities, differences and synergies between what is often termed 'academic' or 'scientific' knowledge and other forms of knowledge. These other forms of knowledge may include local ecological knowledge, traditional ecological knowledge and indigenous ecological knowledge. Overall, many academic scholars struggle to examine these issues in a way that fully captures the nuances, depth, significance and fundamental nature of indigenous knowledge and cultural ecosystem services, which includes how such perspectives are captured in archival sources (Todd 2016).

Because debates over what constitutes a reasonable baseline are notably fierce, any assumptions in this regard should be examined with deep care, consideration and humility by researchers. The conventional use of 'pre-European' contact as a baseline, for example, makes implicit assumptions about the limited role of indigenous peoples in shaping landscapes. However, recent academic research is attempting to do a better job of appreciating the much longer-term use and management of landscapes by indigenous communities. This understanding now includes active landscape management over thousands of years, indicative of complex social-ecological interactions (e.g. creation and management of clam gardens in North America of at least 2000 years old (Jackley et al. 2016); and contemporary plant diversity of Amazonian forests driven by pre-Columbian agriculture (Levis et al. 2017)).

\section{Brief description of key methods}

For the sake of simplicity, we group historical methods by the general source of the information, loosely organised from oldest (most historical) to sources useful for more recent information. On a continuum from oldest to most recent, these categories span sediment cores, archaeological/zooarchaeological materials, dendrochronology/sclerochronology, land surveys,

\section{Case study 25.1: Path dependencies can create poverty traps: long-term analysis of land use}

Historical approaches can improve our understanding of path dependencies in SES. In a study examining poverty traps in Amazonia, Coomes, Takasaki and Rhemtulla (2011) examined whether a household's initial land holdings influenced subsequent land-use decisions, and whether these land-use trajectories resulted in greater poverty. To examine these questions, a combination of aerial photography and satellite imagery from the 1960s, the 1990s and 2007 was used to map land holdings and land cover. Special emphasis was placed on mapping forest age in order to capture differences between primary (intact) forest and agriculture land uses such as crops, orchards and fallow land. Household surveys of income and assets conducted in prior decades were also repeated to assess the contemporary status of households. Together, these datasets created a 30-year record of social-ecological change. 
historical aerial photography, satellite remote sensing, documentary sources, governmental data, interviews and oral histories. Each of these is defined and explained in Table 25.1, which provides a general overview of the types of data and approaches useful in examining long-term SES. Examples from terrestrial, aquatic and marine SES are included (see Tomscha et al. 2016 for more detailed explanations of historical data, and Gergel and Turner 2017 and Chapter 24 of this book for user-friendly advice on using geospatial tools).

\section{Limitations}

Overall, historical assessment can suffer due to the degradation of information sources as one moves back in time. The loss of traditional cultures and languages worldwide has eroded deep traditions of oral histories in many regions, for example. Where subsequent generations recall different memories of SES components, shifting baselines may result, e.g. perceptions of what constitutes a 'large fish catch' may change across generations. In addition, individuals may forget events with the passing of time, making for less accurate recall of events in the deeper past. Poor image quality can reduce the utility of historical maps and photographs, especially when improperly archived (Morgan, Gergel, and Coops 2010). A comparison of the strengths and limitations of local ecological knowledge and remote sensing for long-term assessment is provided by Eddy et al. (2017).

Historical assessment routinely relies on post hoc (after the fact) analyses to infer patterns. Where a statistical approach is needed, it may be constrained by sample-size limitations or a lack of suitable controls (e.g. finding locations that have not been directly affected by human activities). Where sample sizes are limited, trends can be evaluated using a paired $t$-test (at two time periods), repeated measures ANOVA (e.g. three to five measurements over time) or Mann-Kendall tests for roughly 10 or more observations. While causation can potentially be inferred, it can rarely be definitively shown. In many cases mere correlations and associations may result. Finally, understanding the context of historical data (why it was written, who wrote it and who published the documents) is important when it comes to interpreting the

When tracked over three decades, two distinct land-use trajectories were linked to poverty traps. These paths to poverty originated from limitations in farmers' initial land holdings. The first poverty trap was associated with 'land-poor' farmers who focused on subsistence crops. Farmers who were initially 'land rich' were able to devote some of their land to orchard production. Orchards were beneficial in that they produce a higher-value product, but with a delay before planted trees bear fruit. In contrast, land-poor farmers were unable to devote much land to orchards that could only produce benefits in the future. Instead, land-poor farmers focused on immediate but lower-value subsistence crops, ultimately remaining trapped in poverty.

A second poverty trap arose with 'short fallows'. Fallowing is critical to replenish soil fertility prior to another round of cultivation. Farmers with limited land holdings were unable to keep their fallows out of production for very long. As such, their repeated cycles of cultivation with shorter fallows ultimately reduced soil fertility and overall crop production. These path dependencies would not have been evident without a longer-term historical perspective. 
findings. The interpretation of historical sources and data may be heavily influenced by the disciplinary lens and personal experiences or values of the researcher.

\section{Resource implications}

The resource implications vary widely by method and whether primary or secondary data are used. Software is generally required for geospatial analysis of historical imagery. In some cases, data sources such as aerial photography must be purchased (Morgan, Gergel, and Coops 2010). Increasingly, extensive open-data repositories for satellite imagery from sources such as Landsat and MODIS satellites, covering much of the late 20th century, are revolutionising geospatial analysis capabilities. Storage space for data can be a problem, as can confidentiality and anonymity concerns requiring use of encrypted laptops. For participatory mapping, the translation of terms, and the use of terms such as 'degradation' which may not be used in the local language of an area can present real problems for survey implementation and interpretation. Ethics training for any interviews involving human research subjects, especially so for marginalised communities, should be undertaken. Finally, a variety of historical data sources can be labour and time intensive to convert into a usable form and may be impossible to access when historical reports are archived improperly or simply disposed of.

\section{New directions}

Historical assessments may comprise data and methods from multiple fields of research, but research is often still conducted through the lens of a single discipline. Interdisciplinary research between the humanities and social/natural sciences increasingly occurs and fostering this integration will make it possible to answer different, bolder and more innovative research questions. Looking ahead, long-term perspectives must be better incorporated into management and policy to guide efforts to reduce or halt ecosystem degradation or other negative long-term trends. This integration will be aided by technological improvements such as improved optical character recognition and increased access to archival sources via online platforms. Increasing access may enhance connections between individuals and groups of people to share their histories (e.g. transfer of knowledge from elders to the wider society). It may also increase knowledge-sharing platforms for marginalised members of society and so create opportunities to highlight and correct past inequities (e.g. support environmental justice movements).

Enabling 'big data' analyses of historical documents will also create the potential to move from singular place-based assessments to broader-scale comparative analyses. However, increased access to these sources and online platforms also comes with the potential for wider misuse or abuse of historical data and archived cultural memory, through the (intended or unintended) misinterpretation and communication of historical data and/or events.

\section{Key readings}

Crumley, C.L. 1994. Historical Ecology: Cultural Knowledge and Changing Landscapes. Seattle: University of Washington Press.

Kittinger J.N., L. McClenachan, K. Gedan, and L. Blight, eds. 2015. Marine Historical Ecology in Conservation. Applying the Past to Manage for the Future. San Francisco: University of California Press.

Máñez, K.S., and B. Poulsen. 'Of Seascapes and People: Multiple Perspectives on Oceans Past.' Perspectives on Oceans Past 1-10. doi:10.1007/978-94-017-7496-3_1.

Morgan, J.L., S.E. Gergel, and N.C. Coops. 2010. 'Aerial Photography: A Rapidly Evolving Tool for Ecological Management.' BioScience 60(1): 47-59. doi:10.1525/bio.2010.60.1.9. 
Tomscha, S.A., I.J. Sutherland, D. Renard, S.E. Gergel, J.M. Rhemtulla, E.M. Bennett, L.D. Daniels, I.M.S. Eddy, and E.E. Clark. 2016. 'A Guide to Historical Data Sets for Reconstructing Ecosystem Service Change over Time.’ BioScience 66(9): 747-762. doi:10.1093/biosci/biw086.

\section{Acknowledgements}

Sarah Gergel was supported by a Discovery Grant from NSERC, the National Science and Engineering Research Council of Canada. Ruth Thurstan was supported by the European Union's Horizon 2020 research and innovation programme under the Marie SkłodowskaCurie grant agreement (MarHIST No. 787671).

\section{References}

Barbosa, C.C. de A., P.M. Atkinson, and J.A. Dearing. 2015. 'Remote Sensing of Ecosystem Services: A Systematic Review.' Ecological Indicators 52: 430-443. doi:10.1016/j.ecolind.2015.01.007.

Bennett, E.M., G.D. Peterson, and L.J. Gordon. 2009. 'Understanding Relationships among Multiple Ecosystem Services.' Ecology Letters 12(12): 1394-1404. doi:10.1111/j.1461-0248.2009.01387.x.

Braun, V., and V. Clarke. 2006. 'Using Thematic Analysis in Psychology.' Qualitative Research in Psychology 3(2): 77-101. doi:10.1191/1478088706qp063oa.

Buckley, S.M., R.H. Thurstan, A. Tobin, and J.M. Pandolfi. 2017. 'Historical Spatial Reconstruction of a Spawning-Aggregation Fishery.' Conservation Biology 31(6): 1322-1332. doi:10.1111/cobi.12940.

Butler, P.G., and B.R. Schöne. 2017. 'New Research in the Methods and Applications of Sclerochronology.' Palaeogeography, Palaeoclimatology, Palaeoecology 465: 295-299. doi:10.1016/j.palaeo.2016.11.013.

Cohen, W.B., and S.N. Goward. 2004. 'Landsat's Role in Ecological Applications of Remote Sensing.' BioScience 54(6): 535. doi:10.1641/0006-3568(2004)054[0535:LRIEAO]2.0.co;2.

Coomes, O.T., Y. Takasaki, and J.M. Rhemtulla. 2011. 'Land-use Poverty Traps Identified in Shifting Cultivation Systems Shape Long-term Tropical Forest Cover.' Proceedings of the National Academy of Sciences 108(34): 13925-13930. doi:10.1073/pnas.1012973108.

Crumley, C.L. 2017. 'Historical Ecology and the Study of Landscape.' Landscape Research 42(Supplement 1). doi:10.1080/01426397.2017.1399994.

Daniel, T.C., A. Muhar, A. Arnberger, O. Aznar, J.W. Boyd, K.M.A. Chan, R. Costanza et al. 2012. 'Contributions of Cultural Services to the Ecosystem Services Agenda.' Proceedings of the National Academy of Sciences of the United States of America 109(23): 8812-8819. www.internationaleonline. org/research/decolonising_practices/54_decolonial_sensibilities_indigenous_research_and_ engaging_with_archives_in_contemporary_colonial_canada.

Eddy, I.M.S., S.E. Gergel, N.C. Coops, G.M. Henebry, J. Levine, H. Zerriffi, and E. Shibkov. 2017. 'Integrating Remote Sensing and Local Ecological Knowledge to Monitor Rangeland Dynamics.' Ecological Indicators 82: 106-116. doi:10.1016/j.ecolind.2017.06.033.

Fuchs, R., P.H. Verburg, J.G.P.W. Clevers, and M. Herold. 2015. 'The Potential of Old Maps and Encyclopaedias for Reconstructing Historic European Land Cover/Use Change.' Applied Geography 59: 43-55. doi:10.1016/j.apgeog.2015.02.013.

Gebhard, R. 2003. 'Material Analysis in Archaeology.' Hyperfine Interactions 150(1-4): 1-5. doi:10.1023/b:hype.0000007175.85659.15.

Gergel, S.E., and M.G. Turner, eds. 2017. Learning Landscape Ecology: A Practical Guide to Concepts and Techniques (2nd ed). New York: Springer. doi:10.1007/978-1-4939-6374-4.

Gifford-Gonzalez, D. 2018. An Introduction to Zooarchaeology. New York: Springer. doi:10.1007/ 978-3-319-65682-3.

Harland, J., A.K.G. Jones, D.C. Orton, and J.H. Barrett. 2016. 'Fishing and Fish Trade in Medieval York: The Zooarchaeological Evidence.' In Cod and Herring: The Archaeology and History of Medieval Sea Fishing, edited by J.H. Barrett and D.C. Orton. Oxford: Oxbow Books.

Hsieh, H-F., and S.E. Shannon. 2005. 'Three Approaches to Qualitative Content Analysis.' Qualitative Health Research 15(9): 1277-1288. doi:10.1177/1049732305276687.

Jackley, J., L. Gardner, A.F. Djunaedi, and A.K. Salomon. 2016. 'Ancient Clam Gardens, Traditional Management Portfolios, and the Resilience of Coupled Human-Ocean Systems.' Ecology and Society 21(4): 20. doi:10.5751/ES-08747-210420 
Jeffers, E.S., S. Nogué, and K.J. Willis. 2015. 'The Role of Palaeoecological Records in Assessing Ecosystem Services.' Quaternary Science Reviews 112: 17-32. doi:10.1016/j.quascirev.2014.12.018.

Kittinger, J.N., L. McClenachan, K. Gedan, and L. Blight, eds. 2015. Marine Historical Ecology in Conservation. Applying the Past to Manage for the Future. San Francisco: University of California Press.

Last, W.M., and J.P. Smol. 2001. 'An Introduction to Basin Analysis, Coring, and Chronological Techniques Used in Paleolimnology.' In Tracking Environmental Change Using Lake Sediments, Developments in Paleoenvironmental Research, 1-5. doi:10.1007/0-306-47669-x_1.

Levis, C., F.R.C. Costa, F. Bongers, M. Peña-Claros, C.R. Clement, A.B. Junqueira, E.G. Neves et al. 2017. 'Persistent Effects of Pre-Columbian Plant Domestication on Amazonian Forest Composition.' Science 355(6328): 925-931.

McClenachan, L., A.B. Cooper, M.G. Mckenzie, and J.A. Drew. 2015. 'The Importance of Surprising Results and Best Practices in Historical Ecology.' BioScience 65: 932-939. doi:10.1093/biosci/ biv100.

Morgan, J.L., S.E. Gergel, and N.C. Coops. 2010. 'Aerial Photography: A Rapidly Evolving Tool for Ecological Management.’ Bioscience 60(1): 47-59. doi:10.1525/bio.2010.60.1.9.

Newsom, J.T., R.N. Jones, and S.M. Hofer, eds. 2012. Multivariate Application Series, Volume 18. Longitudinal Data Analysis: A Practical Guide for Researchers in Aging, Health, and Social Sciences. Abingdon: Routledge.

Renard, D., J.M. Rhemtulla, and E.M. Bennett. 2015. 'Historical Dynamics in Ecosystem Service Bundles.' Proceedings of the National Academy of Sciences of the United States of America 112(43): 13411-13416.

Rhemtulla, J.M., D.J. Mladenoff, and M.K. Clayton. 2009. 'Historical Forest Baselines Reveal Potential for Continued Carbon Sequestration.' Proceedings of the National Academy of Sciences 106(15): 6082-6087. doi:10.1073/pnas.0810076106.

Rosenberg, A.A., W.J. Bolster, K.E. Alexander, W.B. Leavenworth, A.B. Cooper, and M.G. McKenzie. 2005. 'The History of Ocean Resources: Modeling Cod Biomass Using Historical Records.' Frontiers in Ecology and the Environment 3(2): 84-90.

Selgrath, J.C, S.E. Gergel, and A.C.J. Vincent. 2017. 'Incorporating Spatial Dynamics Greatly Increases Estimates of Long-term Fishing Effort: A Participatory Mapping Approach.' ICES Journal of Marine Science 75(1): 210-220. doi:10.1093/icesjms/fsx108.

Smith, D.J., A.P. Mackie, and I.D. Sumpter. 2005. 'Building Quaksweaqwul: Dendroarchaeological Investigations at Kiix? in National Historic Site, Vancouver Island, Canada.' Dendrochronologia 22(3): 195-201. doi:10.1016/j.dendro.2005.04.004.

Stahle, D.W., and J.S. Dean. 2010. 'North American Tree Rings, Climatic Extremes, and Social Disasters.' Dendroclimatology Developments in Paleoenvironmental Research 11: 297-327. doi:10.1007/ 978-1-4020-5725-0_10.

Thurstan, R.H., Z. Brittain, D.S. Jones, E. Cameron, J. Dearnaley, and A. Bellgrove. 2018. 'Aboriginal Uses of Seaweeds in Temperate Australia: An Archival Assessment.' Journal of Applied Phycology 30: 1821-1832. doi:10.1007/s10811-017-1384-z.

Thurstan, R.H., S.M. Buckley, and J.M. Pandolfi. 2018. 'Trends and Transitions Observed in an Iconic Recreational Fishery Across 140 Years.' Global Environmental Change 52: 22-36. doi:10.1016/j. gloenvcha.2018.06.002.

Todd, Z. 2016. 'An Indigenous Feminist's Take on the Ontological Turn: "Ontology” is just another Word for Colonialism.' Journal of Historical Sociology 29(1): 4-22. doi:10.1111/johs.12124.

Tomscha, S.A., and S.E. Gergel. 2016. 'Ecosystem Service Trade-offs and Synergies Misunderstood without Landscape History.' Ecology and Society 21(1): 43. doi:10.5751/es-08345-210143.

Tomscha, S.A., I.J. Sutherland, D. Renard, S.E. Gergel, J.M. Rhemtulla, E.M. Bennett, L.D. Daniels, I.M.S. Eddy, and E.E. Clark. 2016. 'A Guide to Historical Data Sets for Reconstructing Ecosystem Service Change over Time.’ BioScience 66(9): 747-762. doi:10.1093/biosci/biw086.

UWICER. 2017. Dendrochronology Manual. Ugyen Wangchuck Institute for Conservation and Environmental Research, Department of Forests and Park Services. Bogor: UWICER Press. researchgate.net/publication/325114690_Dendrochronological_Manual.

Wallman, D. 2018. 'Histories and Trajectories of Socio-ecological Landscapes in the Lesser Antilles: Implications of Colonial Period Zooarchaeological Research.' Environmental Archaeology 23(1): 13-22. doi:10.1080/14614103.2017.1345086.

Zusman, A. 2010. Story Bridges: A Guide for Conducting Intergenerational Oral History Projects. Walnut Creek: Left Coast Press. doi:10.4324/9781315419572. 